\title{
New magnetic anomaly map of East Antarctica and surrounding regions
}

\author{
A. Golynsky, ${ }^{1}$ D. Blankenship, ${ }^{2}$ M. Chiappini, ${ }^{3}$ D. Damaske, ${ }^{4}$ F. Ferraccioli, ${ }^{5}$ C. Finn, ${ }^{6}$ D. Golynsky, ${ }^{17}$ \\ A. Goncharov, ${ }^{8}$ T. Ishihara, ${ }^{9}$ S. Ivanov, ${ }^{10}$ W. Jokat, ${ }^{11}$ H.R. Kim,${ }^{12}$ M. König,${ }^{11}$ V. Masolov, ${ }^{10}$ Y. Nogi, ${ }^{13}$ \\ M. Sand, ${ }^{14}$ M. Studinger, ${ }^{14}$ R. von Frese, ${ }^{16}$ and the ADMAP Working Group \\ ${ }^{1}$ VNIIOkeangeologia, 1 Angliysky Avenue, St.-Petersburg, 190121, Russia (sasha@vniio.nw.ru) \\ ${ }^{2}$ University of Texas, Institute for Geophysics, 4412 Spicewood Springs Rd., Bldg. 600, Austin, Texas 78759, USA (blank@ig.utexas.edu) \\ ${ }^{3} \mathrm{INGV}$, via di Vigna Murata, 605, 00143 Roma, Italy (massimo.chiappini@ingv.it) \\ ${ }^{4}$ BGR, Stilleweg 2 D-30655, Hannover, Germany (Detlef.Damaske@bgr.de) \\ ${ }^{5}$ BAS, High Cross, Madingley Road, Cambridge, CB3 OET, UK (FFE@bas.ac.uk) \\ ${ }^{6}$ USGS, Box 25046 Denver, CO 80255, USA (cfinn@usgs.gov) \\ ${ }^{7} \mathrm{SPbSU}, 7 / 9$, Universitetskaya nab., St.-Petersburg, 199034, Russia (Dmitry.A.Golynsky@ gmail.com) \\ ${ }^{8}$ Geoscience Australia, GPO Box 378, Canberra, ACT 2601, Australia (Alexey.Goncharov@ga.gov.au) \\ ${ }^{9}$ GSJ, AIST, 1-1-3, Higashi, Tsukuba, Ibaraki 305, Japan (t-ishihara@aist.go.jp) \\ ${ }^{10}$ PMGRE, 24, Pobeda St., Lomonosov, 189510, Russia (antarctida@ peterlink.ru) \\ ${ }^{11}$ AWI, Columbusstrasse, 27568, Bremerhaven, Germany, (jokat@awi-bremerhaven.de) \\ ${ }^{12}$ GEST/UMBC, Code 698, Planetary Geodynamics Lab. NASA/GSFC, Greenbelt, MD 20771, USA (kimhr@ core2.gsfc.nasa.gov) \\ ${ }^{13}$ NIPR, 1-9-10, Kaga, Itabashi, Tokyo 173, Japan (nogi@nipr.ac.jp) \\ ${ }^{14}$ NPD, Prof. Olav Hanssens Vei 10, PO Box 600, 4003 Stavanger, Norway (morten.sand@npd.no) \\ ${ }^{15}$ LDEO of Columbia University, 61, Route 9W, PO Box 1000, Palisades, NY 10964, USA (mstuding@ldeo.columbia.edu) \\ ${ }^{16}$ OSU, 381, Mendenhall Lab 125 S. Oval Mall, Columbus, OH 43210-1398, USA (vonfrese@ geology.ohio-state.edu)
}

\begin{abstract}
More than 500,000 line-km of new airborne and shipborne data, recently acquired by the international community over East Antarctica and surrounding regions, significantly upgrade the Antarctic Digital Magnetic Anomaly Project (ADMAP) compilation and lead to substantial improvements in magnetic anomaly pattern recognition. New data have been matched in one inverse operation by minimizing the data differences for the areas of overlap. The aeromagnetic data show many previously unknown magnetic patterns, lineaments and trends, defining the spatial extent of Ferrar volcanics and plutonic Granite Harbour Intrusives in the Transantarctic Mountains and previously unknown tectonic trends of the East Antarctic craton. Regional aeromagnetic investigations have successfully delineated Early Paleozoic inherited crustal features along the flanks of the West Antarctic Rift System and the southern boundary of the Archean Ruker Terrane in the Prince Charles Mountains. Magnetic records along the East Antarctic continental margin provide new constraints on the breakup of Gondwana.
\end{abstract}

Citation: Golynsky, A., D. Blankenship, M. Chiappini, D. Damaske, F. Ferraccioli, C. Finn, D. Golynsky, A. Goncharov, T. Ishihara, S. Ivanov, W. Jokat, H. R. Kim, M. König, V. Masolov, Y. Nogi, M. Sand, M. Studinger, R. von Frese and the ADMAP Working Group, New magnetic anomaly map of East Antarctica and surrounding regions in Proceedings of the $10^{\text {th }}$ ISAES, edited by A. K. Cooper and C. R. Raymond et al., USGS Open-File Report 2007-1047, Short Research Paper 050, 4 p.; doi:10.3133/of2007.srp050

\section{Introduction}

Given the extensive ice cover, magnetic surveying is the most effective method to characterize broad areas of sub-ice basement and expand our knowledge of Antarctica. Anomalies arising from the magnetic character of rocks in the earth's crust have revealed many aspects of earth processes and geodynamics, and mapping them comprehensively has been an integral part of many Antarctic expeditions for more than fifty years.

The first generation of the magnetic anomaly map of Antarctica reveals terranes of varying ages, including Proterozoic-Archaean cratons, Proterozoic-Palaeozoic mobile belts, Palaeozoic-Cenozoic magmatic arc systems and other important crustal features (Golynsky et al., 2006a). The map delineates intra-continental rifts and major rifts along the Antarctic continental margin, the regional extent of plutons and volcanics, such as the Ferrar dolerites and Kirkpatrick basalts.

The ADMAP database was produced from air, shipborne and satellite magnetic observations by the international working group of the Antarctic Digital Magnetic Anomaly Project (ADMAP). More than 1.5 million line-kilometres of near surface magnetic recordings were used in the construction of the map (Golynsky et al., 2001). The compilation merged available magnetic survey data collected by the international community from the IGY 1957-58 to 1999. Merging the accumulated anomaly data from marine, aeromagnetic and satellite observations provides a unique continental-scale magnetic anomaly view on the tectonic evolution of the Antarctic crust.

At present, the ADMAP Working Group is working to i) develop a DVD with its point data compilation up to 1999 for release to the World Data Centers, ii) implement ADMAP's protocols and to maintain and update the database as new magnetic survey data become available, iii) improve models of the Antarctic core field, iv) compile rock magnetic and other physical properties to support geological applications of the ADMAP database, and v) support the World Magnetic Anomaly Map initiative of the International Association of Geomagnetism and Aeronomy.

\section{New data sets}

Several international programs have focused on the first-order geophysical mapping of tectonic and geologic structures in the interior of East Antarctica and along its 
continental margins. As shown in Figure 1, they have resulted in a large amount of aero- and shipborne magnetic surveying since the end of the last century.

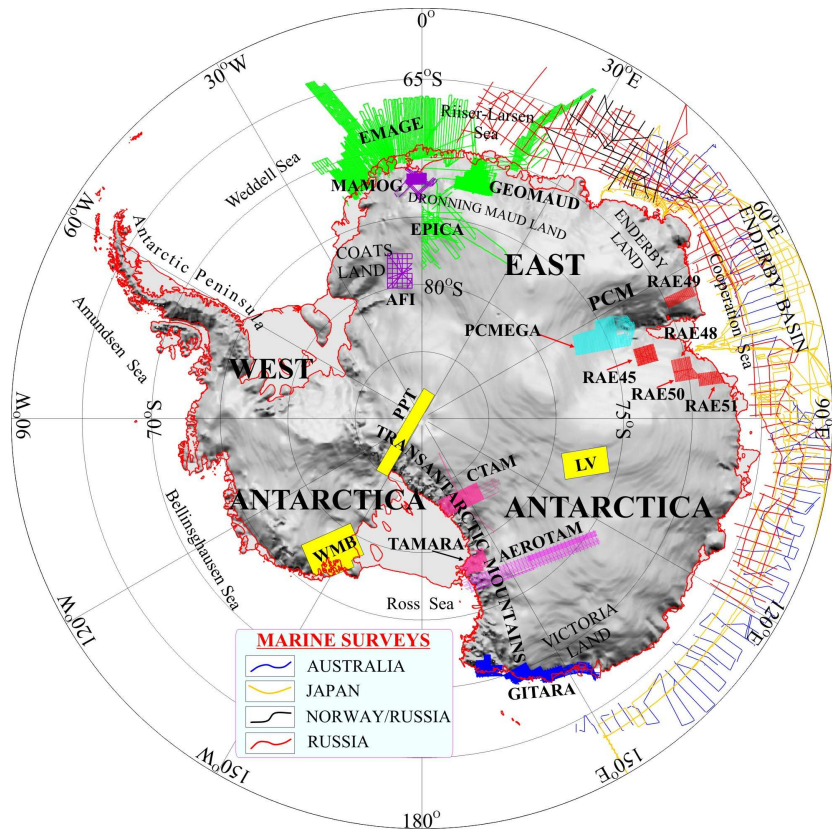

Figure 1. Line coverage of recently acquired near surface magnetic surveys used in this study. Map projections throughout this paper are polar stereographic. The coastline is from the Antarctic Digital Database. See Table 1 for survey specifications. PCM - Prince Charles Mountains.

One of the largest aeromagnetic datasets was collected by the Alfred Wegener Institute (AWI) over western Dronning Maud Land (DML) and its continental margin since the austral summer of 1996/97 (Jokat et al., 2003). Within the East Antarctic Margin Aeromagnetic and Gravity Experiment (EMAGE) project, a total of 90,000 $\mathrm{km}$ of aeromagnetic data were acquired along a $1200 \mathrm{~km}$ long segment of the East Antarctic coast. The aircraft flight pattern between $18^{\circ} \mathrm{W}$ and $8^{\circ} \mathrm{E}$ was extended by two helicopter surveys $(\sim 20,000 \mathrm{~km})$ during the 1999/2000 season.

Traditionally the Indo-Antarctic continental margin is the sphere of scientific interest of Australian, Japanese, and Russian researchers who conducted several recent cruises into this region. The programs of the Polar Marine Geological Research Expedition (PMGRE, Russia) and Geoscience Australia (GA) acquired an integrated geophysical survey dataset including seismic, gravity and magnetic information of more than 50,000 and 20,000 line-km, respectively, along the continental margin of East Antarctica, west of the Astrid Ridge to George V Coast of Victoria Land (Gandyukhin et al., 2006, Stagg et al., 2005). Similar sets of geophysical data were collected by the Norwegian/Russian and Japanese expeditions in the Cosmonaut and Cooperation Seas (e.g. Joshima et al., 2001).
Aeromagnetic flights over East Antarctica have concentrated in the major regions of the Transantarctic Mountains (TAM), the Prince Charles MountainsLambert Glacier area, and western Dronning Maud Land - Coats Land. Additionally two surveys were acquired over Lake Vostok and in the western part of Mary Byrd Land. The majority of these projects ultimately succeeded in simultaneously operating and integrating laser altimetry, ice-penetrating radar, gravity, and magnetics aboard survey aircraft/helicopters (Figure 1; Table 1).

\section{Map compilation}

Evaluation of the creditability of any magnetic anomaly compilation depends on characterizing the input data and procedures used for their processing. The processing of recently acquired data was achived in several consistent steps. First, the processing of all recently acquired shipborne surveys by the PMGRE were re-examined. The magnetic data were edited for highfrequency errors, levelled and adjusted, and the data quality assessed by statistical analysis of the crossover errors. The mean square error (MSE) for these datasets varied from 2.5 to $12.0 \mathrm{nT}$, and suggested that these shipborne surveys were some of the highest quality of any carried out in the Antarctic.

Pre-processing of the GA and Norwegian track-lines allowed us to create a new dataset of only the recently gathered GA, NPD and PMGRE information. The subsequent cross-over analysis showed that they are levelled accurately. An internal adjustment of unified data set was performed iteratively by applying to the GA and NPD lines constant magnetic offsets derived from a crossover analysis. The MSE of the combined dataset does not exceed $11.9 \mathrm{nT}$. This result would not be possible in the absence of the tie-lines conducted by the PMGRE within individual surveys and between neighboring surveys. This result ensured us that the new unified dataset can be used as a base net for the subsequent levelling of other information collected by international institutions along the East Antarctic continental margin.

Thus, a new compilation for the marine study area was produced which contained the above mentioned datasets, the Japanese (JARE40-42, TH98-99) lines, and all previous ADMAP marine magnetic profiles. An internal adjustment of the data set was done in similar way to the earlier line-network adjustment. Successive data gridding and imaging was used to examine the spatial correlation of magnetic lines and to identify the erroneous lines that may produce extreme distortions of magnetic anomalies. Levelling the united dataset for the entire study area reduced the initial MSE from 60.8 to $20.6 \mathrm{nT}$.

The patchwork merging of recently acquired aeromagnetic data with the ADMAP surveys requires levelling adjustments. These procedures were treated individually according to whether the survey data were available in grid form or as profiles. Large overlapping areas between the PMGRE and PCMEGA profile data in the Prince Charles Mountains (PCM) region allowed us to 
determine a datum shift between individual surveys rather accurately (138 nT). The irregular networks of older regional profiles over the Transantarctic Mountains were re-levelled using the CTAM project data. Other sets were knitted together by their overlapping areas. The final compilation merged the aeromagnetic and marine grids to create the master grid over East Antarctica and surrounding areas with minimal mismatch between the data sets along their boundaries as shown in Figure 2. The adjusted magnetic data were interpolated onto a $5 \mathrm{~km}$ grid using a minimum curvature algorithm.
Lithospheric magnetic anomalies were extracted from CHAMP satellite data and merged with ship and airborne magnetic surveys compiled within this study. Employing spectral correlation theory to filter the static lithospheric field components from the dynamic external field effects, we processed the CHAMP satellite magnetic observations for an improved magnetic anomaly map of the Antarctic crust. These results greatly facilitate predicting magnetic anomalies in the regional data coverage gaps (Kim et al., in press).

Table 1. Specifications of new airborne (1) and shipborne (2) surveys used in this study.

\begin{tabular}{|c|c|c|c|c|c|c|}
\hline Organisation & Project & Country & Year & Line-km & Line spacing, km & Reference \\
\hline${ }^{1}$ AWI & EMAGE & Germany & $1996-2002$ & 110,000 & $10 / 20$ & Jokat et al., 2003 \\
\hline${ }^{1}$ AWI & EPICA & Germany & $1996-1999$ & 13,600 & variable & not published \\
\hline${ }^{1}$ BAS & MAMOG & Great Britain & $2001 / 02$ & 15,500 & 1 & Ferraccioli et al., 2005 \\
\hline${ }^{1}$ BAS & AFI & Great Britain & $2001 / 02$ & 5,000 & 30 & Shepherd et al., 2006 \\
\hline BGR & GEOMAUD & Germany & $1995 / 96$ & 14,800 & 4.4 & Damaske, 1999 \\
\hline${ }^{1}$ BGR/U.Genova & GITARA & Germany/Italy & $1999-2000$ & 19,000 & 4.4 & Damaske et al., 2003 \\
\hline${ }^{1}$ BGR/U.Melb & PCMEGA & Germany/Australia & $2002 / 03$ & 29,800 & 5 & Damaske \& McLean, 2005 \\
\hline${ }^{1}$ PMGRE & RAE45-50 & Russia & $2000-05$ & 27,900 & 5 & Golynsky et al., 2006b \\
\hline${ }^{1}$ SOAR & PPT & USA & $1998 / 99$ & 13,000 & 10 & Studinger et al., 2006 \\
\hline${ }^{1}$ SOAR & WMB & USA & $1998 / 99$ & $37,000 ?$ & $5.3 / 10.6$ & Luyendyk et al., 2003 \\
\hline${ }^{1}$ SOAR & AEROTAM & USA/Italy & $1999-2000$ & 21,000 & $5.3 / 10.6$ & Studinger et al., 2004 \\
\hline${ }^{1}$ SOAR & Lake Vostok & USA & $2000 / 01$ & 20,000 & 7.5 & Studinger et al., 2003 \\
\hline${ }^{1}$ USGS/BGR & CTAM & USA/Germany & $2003 / 04$ & 32,000 & $1.25 / 2.5$ & Anderson et al., 2006 \\
\hline${ }^{1}$ USGS/BGR & TAMARA & USA/Germany & $1997 / 98$ & 14,100 & 2.5 & Damaske et al., 2002 \\
\hline${ }^{2}$ GA & AASOPP & Australia & $2001 / 02$ & 20,000 & $80-100$ & Stagg et al., 2005 \\
\hline${ }^{2}$ JNOC/GSJ & TH98-99 & Japan & $1998 / 2000$ & 15,000 & variable & Joshima et al., 2001 \\
\hline${ }^{2}$ NIPR & JARE40-42 & Japan & $1999-2001$ & 39,700 & variable & not published \\
\hline${ }^{2}$ NPD/PMGRE & NPD/PMGRE & Norway/Russia & $2002-04$ & 8,000 & variable & not published \\
\hline${ }^{2}$ PMGRE & RAE41-50 & Russia & $1996-2005$ & 50,000 & $70-80$ & Gandyukhin et al., 2006 \\
\hline
\end{tabular}

\section{Tectonic implications}

The more than 240,000 line-km of new terrestrial magnetic observations for the East Antarctic continental margin lead to essential improvements in definition of magnetic anomaly patterns compared to the first ADMAP compilation. Aeromagnetic data collected by the AWI along the eastern Weddell Sea and Riiser-Larsen Sea continental margins provide new constraints on the timing and geometry of the early Gondwana breakup (Jokat et al., 2003).

Results of the compilation do not radically alter recent models describing first-order motion between the Antarctic, Australian and Indian plates, but they help resolve uncertainties about the early break-up histories of opening between these plates. It is highly likely that spreading in the Enderby Basin occurred around the same time as anomalies M10 to M0 were formed off the Perth Basin, Western Australia (Gandyukhin et al., 2006; Gaina et al., 2003). The history of the early spreading is complicated by the likelihood of one or several ridge jumps in which most of early seafloor crust was transferred to the Antarctic plate. Additionally, a large amount of the oceanic crust is now probably overprinted by igneous activity associated with the Kerguelen Plume, which began forming the Kerguelen Large Igneous Province from about 120-110 Ma.

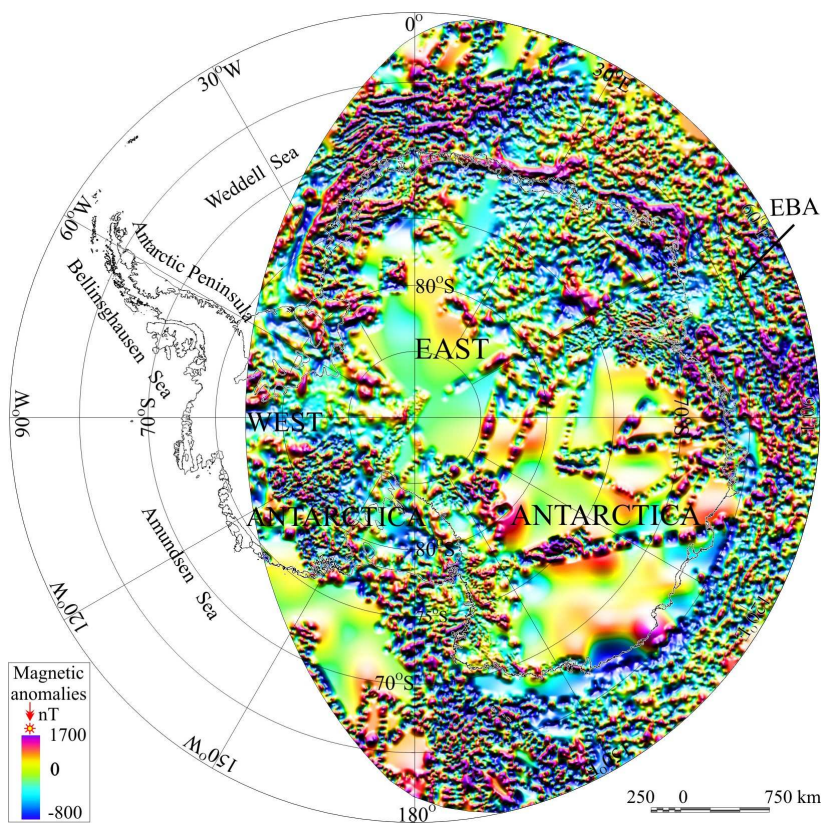

Figure 2. New colour shaded-relief magnetic anomaly map of East Antarctica and surrounding regions. Illumination is from the North at an inclination of $45^{\circ}$. EBA - the Enderby Basin Anomaly. See Plate 1 for large map. 
Among other noteworthy peculiarities of the magnetic field is the curvilinear belt of positive magnetic anomalies running parallel with the coast of Enderby Land and MacRobertson Land, which we have named the Enderby Basin Anomaly (Figure 2). It extends from the western margin of Kerguelen Plateau up to the Gunnerus Ridge and appears to be associated with the continent-ocean boundary identified on the basis of seismic data.

Over the continent, the new data allow us to recognize previously unknown magnetic features and patterns including pronounced magnetic lineaments and trends that reveal, for example, the spatial extent of Ferrar volcanics and plutonic Granite Harbour Intrusives in the TAM and other unknown tectonic trends of the East Antarctic craton (Ferraccioli et al., 2005; Golynsky et al., 2006b; Studinger et al., 2003, 2006). Regional aeromagnetic investigations have been successful in delineating Early Paleozoic inherited crustal features along the flanks of the West Antarctic Rift System (Finn et al., 1999; Ferraccioli et al., 2002). The new magnetic data help characterize the subice geology south of the PCM and define more accurately the southern boundary of the Archean Ruker Terrane.

\section{Conclusions}

Recent magnetic anomaly data acquired by the international community over the East Antarctica and surrounding regions upgrade the ADMAP compilation substantially. More than 500,000 line-km of new airborne and shipborne data have been matched by inversion to minimize the data differences within overlapping areas. These results provide a new and uniform window through which tectonic structures and lithologies of the East Antarctic Shield can be studied. The new map also shows where gaps in the data coverage still remain, thereby focusing the attention on areas where new data acquisitions would significantly enhance our knowledge of the Antarctic craton.

Acknowledgments. We are grateful to all members of the ADMAP Working Group for their contributions. Peter Milligan and W. Rack are thanked for helpful reviews. Review of the manuscript by Fred Davey is gratefully acknowledged.

\section{References}

Anderson, E. D., C. A. Finn, D. Damaske, J. D. Abraham, F. Goldmann, J. W. Goodge, P. Braddock (2006), Aeromagnetic and gravity data over the Central Transantarctic Mountains (CTAM), Antarctica, Open-File Report 2006-1255.

Damaske, D. and M. McLean (2005), An aerogeophysical survey south of the Prince Charles Mountains, East Antarctica, Terra Antartica, 12(2), 87-98

Damaske, D., F. Ferraccioli and E. Bozzo (2003), Aeromagnetic anomaly investigations along the Antarctic Coast between Yule Bay and Mertz Glacier, - Terra Antartica, 10(3), 85-96.

Damaske, D., C. A. Finn, H-D Moeller, C. Demosthenous, and E. D. Anderson (2002), Aeromagnetic data centered over Skelton Neve, Antarctica, Open-File-Report 02-452.

Damaske, D. (1999), Merging aeromagnetic data collected at different levels: the GEOMAUD survey, Annali Di Geofisica, vol. 42, N. 2, 153-159.

Ferraccioli, F., E. Bozzo, G. Capponi (2002), Aeromagnetic and gravity constraints for an early Paleozoic subduction system of Victoria Land,
Antarctica. Geophys. Res. Lett. 29(10), 1406, doi:10.1029/201GL0141138.

Ferraccioli, F., P. C. Jones, M. L. Curtis, P. T. Leat, and T. R. Riley (2005), Tectonic and magmatic patterns in the Jutulstraumen rift (?) region, East Antarctica, as imaged by high-resolution aeromagnetic data, Earth Planets Space, 57, 767-780.

Finn, C, D. Moore, D. Damaske, \& T. Mackey (1999), Aeromagnetic legacy of early Paleozoic subduction along the Pacific margin of Gondwana, Geology, 27, No. 12, 1087-1090.

Gaina, C., R. D. Müller, B. Brown, and T. Ishihara (2003), Microcontinent formation around Australia, in: Hillis R. R. and Müller R. D. (eds.), Evolution and Dynamics of the Australian Plate, Geological Society of Australia Special Publication 22 and Geological Society of America Special Paper 372, Chapter 26, 399-410.

Gandyukhin, V. V., L. A. Kuznetsova, A. I. Kuznetsov, M. A. Fedorova, S. V. Ivanov, A. Yu. Kazankov (2006), Marine geophysical studies in the Davis Sea, East Antarctica, Russian Earth Science Research in Antarctica, Vol1, St.-Petersburg, 94-100.

Golynsky, A., M. Chiappini, D. Damaske, F. Ferraccioli, C. Finn, M. Ghidella, T. Ishihara, H. R. Kim, L. Kovacs, V. Masolov, P. Morris, Y. Nogi, R. von Frese (2006a), ADMAP - A digital magnetic anomaly map of the Antarctic, in Antarctica - Contributions to Global Earth Sciences, edited by D. K. Fütterer, D. Damaske, G. Kleinschmidt, H. Miller, F. Tessensohn, Springer-Verlag, Berlin Heidelberg New York, 109-116.

Golynsky, A. V., V. S. Volnukhin, D. A. Golynsky, V. O. Leonov, A. V. Kiselev (2006b), Magnetic anomaly field of MacRobertson Land and its possible geological origin (airborne geophysical survey during the 49-th Russian Antarctic Expedition), Russian Earth Science Research in Antarctica, Vol1, St.-Petersburg, 116-126.

Golynsky, A., M. Chiappini, D. Damaske, F. Ferraccioli, J. Ferris, C. Finn, M. Ghidella, T. Ishihara, A. Johnson, H. R. Kim, L. Kovacs, J. LaBrecque, V. Masolov, Y. Nogi, M. Purucker, P. Taylor, and M. Torta (2001), ADMAP - Magnetic Anomaly Map of Antarctic, in BAS (Misc.) 10, edited by P. Morris and R. von Frese, Cambridge, BAS.

Joshima, M., T. Ishihara, T. Nakajima, K. Sugiyama, K. Tsuchida, A. Kato, F. Murakami, and B. Brown (2001), Preliminary results of the TH99 geological and geophysical survey in the Cooperation Sea and Prydz Bay area, Polar Geoscience, NIPR, 14, 244-262.

Jokat, W., T. Boebel, M. König, and U. Meyer (2003), Timing and geometry of early Gondwana breakup, J. Geophys. Res., 108, No B9, 2428.

Kim, H. R., R. R. B. von Frese, P. T. Taylor, A. V. Golynsky, L. R. Gaya-Piqué, and F. Ferraccioli (in press), Improved magnetic anomalies of the Antarctic lithosphere. Geoph. J. International.

Luyendyk, B. P., D. S. Wilson, and C. S. Siddoway (2003), Eastern margin of the Ross Sea Rift in western Marie Byrd Land, Antarctica: Crustal structure and tectonic development, $\mathrm{G}^{3}, 4(10), 1090$.

Shepherd, T., J.L. Bamber, and F. Ferraccioli, (2006), Subglacial geology in Coats Land revealed by airborne magnetics and radar sounding, Earth Planet. Sci. Lett., 244, 323-335.

Stagg, H. M. J., J. B. Colwell, N. G. Direen, P. E. O'Brien, B. J. Brown, G. Bernardel, I. Borissova, L. Carson, and D. B. Close (2005), Geological framework of the continental margin in the region of the Australian Antarctic Territory, Geoscience Australia Record 2004/25, $356 \mathrm{p}$

Studinger, M, R. E. Bell, G. D. Karner, A. A. Tikku, J. W. Holt, D. L. Morse, T. G. Richter, S. D. Kempf, M. E. Peters, D. D. Blankenship, R. Sweeney, V. L. Rystrom (2003), Ice cover, landscape setting, and geological framework of Lake Vostok, East Antarctica, Earth Planet. Sci. Lett., 205, 195-210.

Studinger M, R. E. Bell, R. Buck, G. D. Karner, D. D. Blankenship (2004), Sub-ice geology inland of the Transantarctic Mountains in light of new aerogeophysical data, Earth Planet. Sci. Lett., 220, 391408 .

Studinger, M., R. E. Bell, P. G. Fitzgerald, W. R. Buck (2006), Crustal architecture of the Transantarctic Mountains between the Scott and Reedy Glacier region and South Pole from aerogeophysical data, Earth Planet. Sci. Lett., 250, 182-199. 